\title{
SUSTAINABLE ACTIONS FOR URBAN AND TERRITORIAL RE-GENERATION
}

\author{
DONATELLA CIALDEA \\ L.a.co.s.t.a. Laboratory University of Molise, Campobasso, Italy.
}

\begin{abstract}
Urban regeneration should have a role of integration between planning and design activities; moreover, it very often looks like a single project with detailed proposals and performances, without a general vision of the area. It is therefore necessary to build a reference for the design choices, which primarily concern the city but increasingly involve the surrounding territory. This paper explores the relationship between the plurality of factors that exist on the settlements and productive activities assets which are the elements of the coastal landscape. Our work aims to deal with every aspect of the Re-generation potential, which is an opportunity for enrichment of urban planning, especially in the cases of the Regions - as Molise is - in which really cities do not exist but there is a "continuum" between adjoining Municipalities in a mainly rural territory. Moreover, coastal areas have been in recent years the privileged place for interventions guided by the principles of urban regeneration, in the first phase focused on the physical rehabilitation of degraded areas, afterwards including attention to cultural, social, economic and environmental aspects. In the evolution of this phenomenon, not only we need to highlight the shift from physical rehabilitation to urban regeneration, as an integrated process of actions with a focus on the social aspect, but also we must underline that the so-called "complex programs" - utilized for regeneration projects - are more dynamic than the traditional plans.
\end{abstract}

Keywords: sustainability, urban regeneration, waterfronts \& harbors.

\section{INTRODUCTION}

Our aim is the creation of a spatial analysis model, able to relate coastal transformations with planning tools, territorial and urban, and with sustainability indicators. Through the selection of planning and design examples of regeneration projects in coastal areas in the National and International scene, and the creation of a best practices abacus and keywords, a methodology for the creation of sustainability indicators of urban regeneration was developed.

The understanding of the coastal landscape, its layers of history, its architectural heritage and its building settlement features, near or within urban areas, allows us to identify and analyze the characteristics of the landscape and simultaneously evaluate the applicability of the analysis methodology.

The relationship between land/coast and water/sea is stronger along the coastline, in which the relationship between urban and natural element is closer, where City and Sea live together to create the coastal landscape. Water adds value to villages, and this is demonstrated by the constant interest of urbanism that, in recent decades, has examined in depth issues regarding the "water renaissance", i.e. all potential processes of regeneration of the waterfront areas [1-6].

The waterfront, however, unlike the coastline, cannot be considered a simple demarcation between water and land, but it is, however, a portion of land in close relationship with the sea, and people, over the centuries, redesigned and shaped urban settlements and infrastructure.

This great interest in designing and planning regeneration projects, led many researchers at National and International level to set out several principles and guidelines on issues of 
coasts and resilient waterfronts, that would be able of adapting changes to ecological and sustainable models [7-10].

The change of the city model, with the gradual disposal of industrial areas and new environmental sustainability policies - oriented to the lower consumption of land - encourages these new instruments. Moreover, the participation of local actors in the decision-making process increases social cohesion and effectiveness of policies.

In Italy, in the absence of National normative references, some regions planned new experimental forms aimed to free the urban regeneration policies from the stiffness of traditional planning tools.

The Puglia Region, as part of its renewal legislative planning framework, in 2008 enacted the Regional law "Norms for the urban regeneration" [11]. It is the first and unique case in our National scenario and it aims to integrate the EU principles within the ordinary management tools. Later, also the Toscana Region in 2014 included in its Regional Law "Norms for the Territory Management" regeneration processes for degraded urban areas [12].

\section{METHODOLOGY AND OBJECTIVES}

The methodological approach for inserting sustainability indicators in territorial regeneration is described in Fig. 1.

We analysed results of research and documents related to Sustainable Cities. The conference proceedings as "Aalborg Commitments" arising from the Fourth European Conference

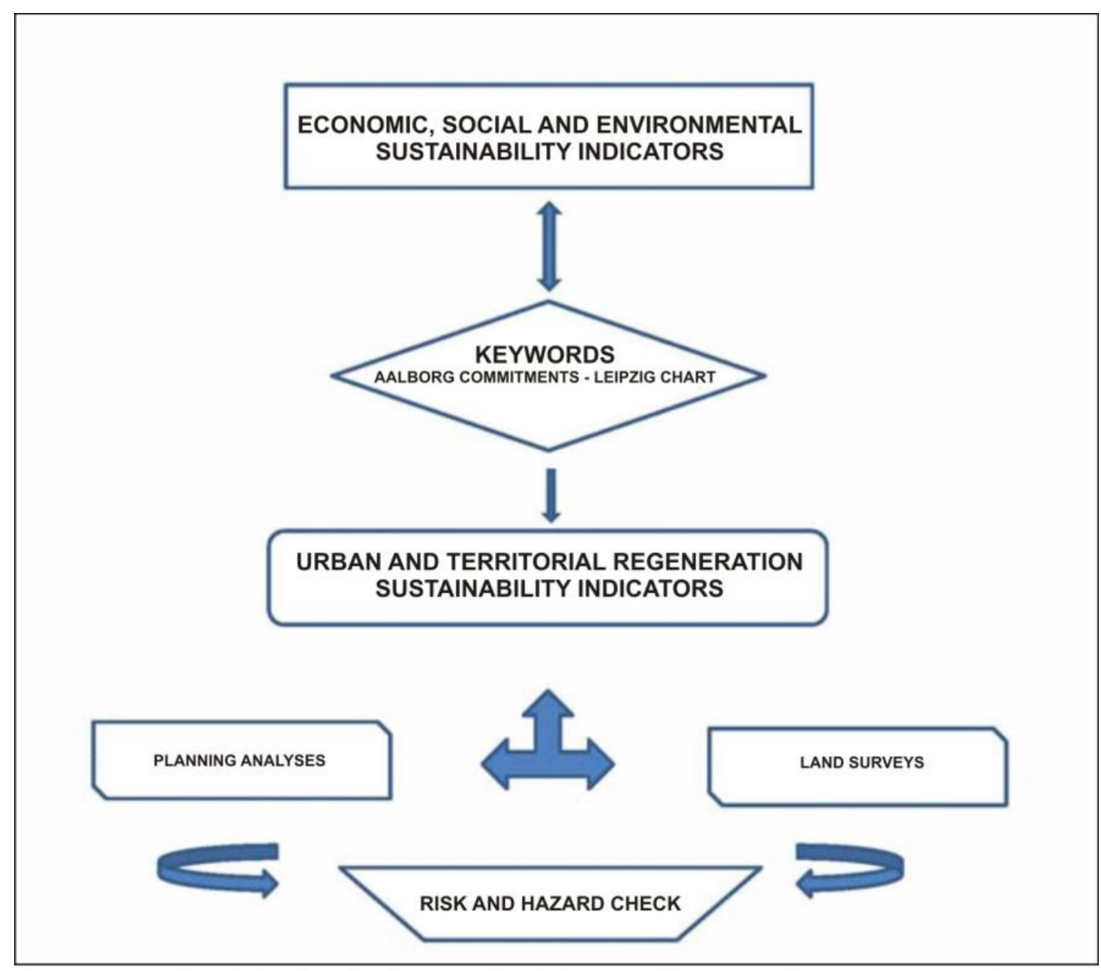

Figure 1: Spatial Analysis Methodology (Source: 1.a.co.s.t.a. Laboratory Processing 2013). 
of Sustainable Cities, the "Leipzig Chart on Sustainable European Cities", and "10 principles for Sustainable Development of Urban Waterfront" and related remarks were reviewed [13-19].

The "Aalborg Commitments", addressed fundamental issues to revitalize, regenerate derelict or disadvantaged areas and prevent uncontrolled urban expansion. This document focuses on the governance of these processes, the local management towards sustainability - exploitation of natural resources, responsible consumption and improvement in lifestyles, planning and urban design, improving mobility and reducing the traffic, local action for health, sustainable local economy, equity and social justice, and the development of local responses to global problems such as climate change - to address integrated environmental, social, economic, health and cultural issues.

Other ideas for the urban regeneration of the waterfront have been identified in the Leipzig Chart on Sustainable European Cities, signed by the Member of the EU members in 2007. The document highlights the need for strategies aimed at integrated urban development through actions for modernizing infrastructure networks and improving energy efficiency, oriented to proactive innovation and encouragement of educational policies.

Interesting guidelines for planning the waterfront regeneration are " 10 principles for sustainable development of urban Waterfront", which can be summarized in the need to ensure quality of water and environment; to include the waterfront into the existing urban asset; to recognize the historical identity that gives character to sites; to prioritize mix functions; to guarantee public access to water; to promote public-private partnerships; to promote sustainability not only from environmental and economy point of view, but also on a social level; to promote a long-term project; to revitalize through a continuous process; to promote international cultural exchanges.

Moreover, we analysed the results of "The Seven principles for creative urban waterfronts" [20]. It shows how the recognition of identity (cultural, economic and social)" and "skills" of action require a system that users are willing to interact. Economic sustainability must allow a safe implementation of actions, including facilitating or forms of tax relief. The unspoken transformation potential could be transformed into energy planning.

New suggestions derived also from the regeneration projects of the New York waterfront.

The guidelines "Waterfront Smart Growth" [21] and the examined examples for the American waterfront concern the multiplicity of land use. The waterfront is a place full of vitality, where the dynamism of activities, mainly trade, is part of the presence of infrastructure, pedestrian walkways, residential areas, public spaces.

Moreover, the compact city and its waterfront are a natural border which prevents its expansion into the suburbs, limiting the agricultural and natural land use and combining housing needs of residents and seasonal people.

The immediate goal could be the strengthening of land and sea transport, to walk, ride your bicycle or take public transportation to get to the shops, work and school, all actions able to reduce air pollution and traffic congestion.

The incentive policies for the regeneration of the waterfront, new development and new investments in these areas can regenerate those commercial corridors and provide new incentives to strengthen the local economy.

Moreover, the strategic management tool of the NYC waterfront, called Vision 2020 [22], focuses on public access to the waterfront and waterways; on the revitalization of the waterfront with integrated uses that could attract the hinterland communities; on supporting economic development activities; on the improvement of water quality; on the restoration of 
degraded waterfront and on protection of wetlands and coastal natural habitats; on the enlargement of the "Blue Network" of public waterways surrounding New York; on the improvement of legislation for the coordination and supervision of the waterfront activities; on the identification of strategies to increase the strength of the city to change, including the climate change and the rising sea level.

In addition to the strategic plan, the city of New York also features the Waterfront Revitalization Program (WRP) [23, 24] with the goal of maximizing the benefits from economic development, environmental protection and public use of the waterfront, minimizing conflicts between these objectives.

The WRP development policies are: residential and commercial redevelopment; industrial and maritime development; the use of waterways; ecological resources; the water quality; flooding and erosion; hazardous materials; public access to the waterfront; landscape resources; and the historical and cultural resources.

In conclusion, this first phase of our work has involved the analysis of the cited theory documents looking for best practices and keywords to be used as filters for the selection of indicators for urban and regional regeneration of the waterfront.

At the same time, indicators of environmental sustainability were examined. The indicators used to assess the sustainability were selected from those processed by the National Economy and Work Council (CNEL) [25, 26], and sets dashboard indicators widely used by International Institutions.

They consist of nature indicators more varied: some have a general nature, others very specific. They may be specified directly in connection with the development, sustainability or both of them. An example is the European Union's list, which includes nine topics and over 100 indicators for monitoring progress made by the European Union in terms of sustainable development as defined in the context of Sustainable Development strategy drawn up in 2006 [27].

Another example is triggered by the Commission of the United Nations for monitoring Sustainable Development (CSD) in 1992 [28] based on 58 indicators excerpted from an initial list of 134 and covering the economic, environmental, social and institutional sustainable development.

Other examples are the Index of Economic Well Being (IEWB) [29], the Sustainable Measure of Economic Well-Being (SMEW) [30], the Index of Genuine Saving from the World Bank [31], and the Ecological Footprint [32].

The composite indicators have the goal of building a synthetic index that could express the large quantity of information that comes from the statistics in such a way as to allow comparisons.

Our final work involving the selection of sustainability indicators came from the documents and project analysis. Through this method of matching keywords and best practices for the regeneration of the waterfront, with the indicators of sustainability, a new set of indicators was created, called sustainability of urban and regional regeneration, useful in the analysis of planning and programming documents to define the areas of sustainability and risk.

\section{SUGGESTIONS FOR COASTAL RE-GENERATION}

Our methodology was tested in the case of the waterfront transformation in Molise. In this part of the Adriatic coast there are a number of significant actions in progress.

The region, in general, has a low coast with tracts of mountainous coastal areas near the town of Termoli, which is set upon a promontory and it is the most important regional port: 
built in 1905 (originally intended to be built in 1890 it did not then obtain authorization), it has since been subject to further development.

Along the coast, however, we also have the presence of industrial areas, and large infrastructures, which also happen to be the most important structures of the region, as well as tourist areas. The industrial area of Termoli is without doubt the most important of the region; its presence since the early 70's has led to the formation of a new territorial structure with a relative increase in population in the whole of the surrounding area.

In our study, this part of the regional territory was analyzed, as it results from our landscape analyses, made by virtue of the mission received from the Molise Region for the preparation of the New Landscape Plan, under the new Code for Cultural and Landscape Heritage.

In particular, we have chosen the area near the main infrastructures, existing and under construction, i.e. the Port area, the Adriatic railway, the State Road 16, the Highway A14 and the Inter-Port; the latter, under construction, will occupy the northern part of the Consortium for Industrial Development of the Biferno Valley (COSIB) [3, 5].

A Geographic Information System (G.I.S.) was created, in order to compare different Plans and find any possible inconsistencies. After entering our metadata in G.I.S., we proceeded to examine Plans or projects in the sample area.

An analysis of the Actual Landscape Plan, PTPAAV No. 1, shows that in this area there is only medium sensitivity to transformation zones (they are classified as MV1/Areas with high level exclusive visual value and MS/Settlement system areas with moderate visual value), with the exception of the coastal strip between the harbour and the mouth of the Biferno River (classified as A2N1/Coasta strip strongly characterised by natural elements), and the two areas "La Gatta" and "Vallone Rio Vivo" (A2N2/Areas with natural vegetation of exceptional visual and naturalistic value).

In the MV1 homogeneous area, which contains the Termoli Industrial Core, most uses are permitted with the TC1/Conditioned Transformation transform mode.

In the MS area, which contains almost the entire town of Termoli, all uses are permitted with the TC1 transform mode.

In A2N1 and A2N2 areas, however, transformations are not supported, but only the maintenance of existing uses (Fig. 2).

Indicators of urban and territorial regeneration sustainability, have been used to examine more recent norms, and especially for the Port Master Plan, comparing it with the obsolete City Master Plan.

This comparison shows that the Master Plan pays attention to the aspects of environmental and economic sustainability, rather than those related to social sustainability and landscape perception.

In particular, it pays attention to the production of energy from renewable sources, to the improvement of the transport of people and goods services, to policies for the separate collection of municipal waste, to the limitation of emissions into the atmosphere, as well as status monitoring water, and the protection of natural areas.

However, it neglected aspects such as social participation in planning processes and land management or the quality of services to citizens. It does not take into consideration aspects of landscape transformation, except for certain actions linked to the erosion of the coastline.

The territorial analysis showed, within the study, that it is a highly critical area which would require the urban and regional regeneration policy specifications. This area is currently 


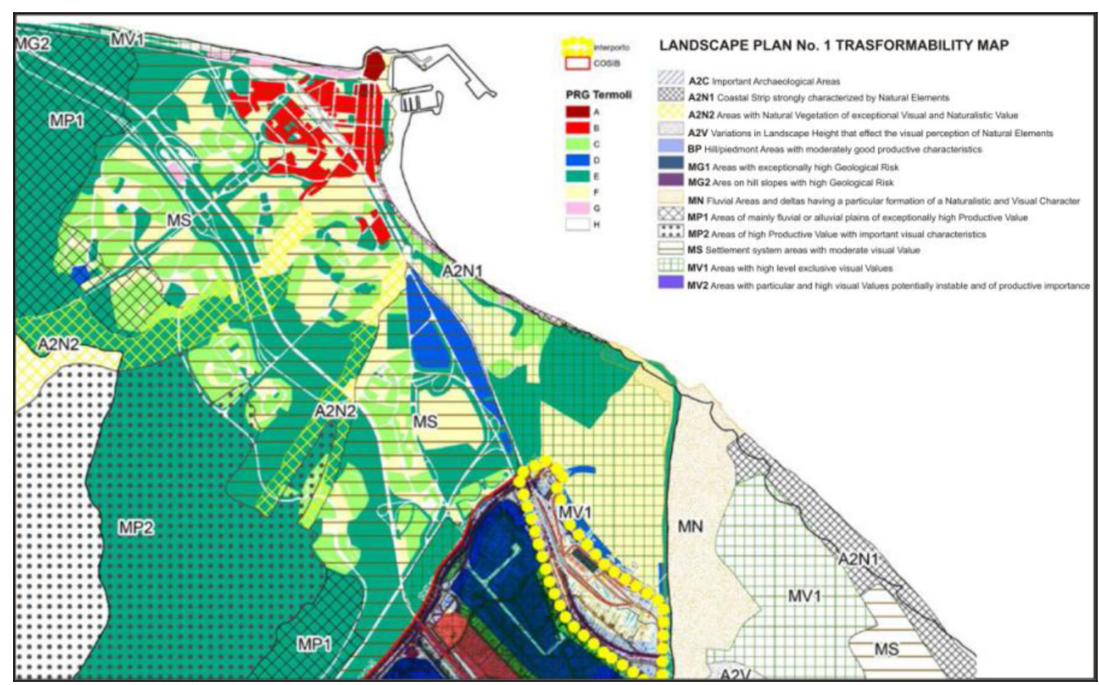

Figure 2: Analysis of the landscape aspects in the sample area (Source: Regione Molise P.T.P.A.A.V. n. 1, Processing Laboratory 1.a.co.s.t.a. 2014).

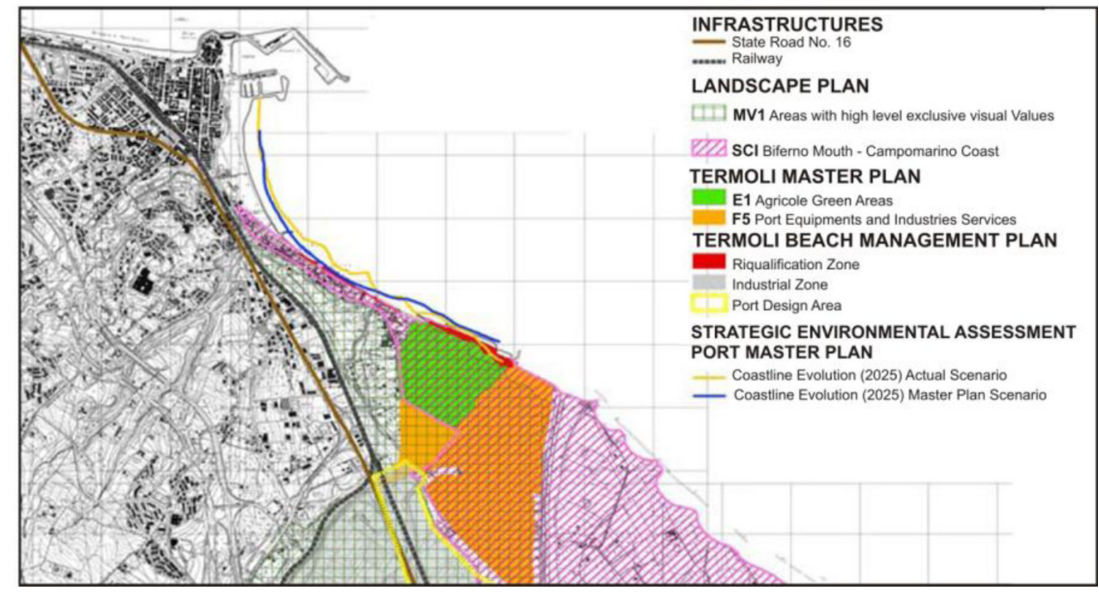

Figure 3: Overlapping Plans (Source: Regione Molise, Municipality of Termoli, Quercio 2015 Processing Laboratory l.a.co.s.t.a. 2013).

classified in the existing City Master Plan as an agricultural area (E1), but densely urbanized and strongly marked by the Adriatic railway. The simulation of the evolution of the coastline in this area contained in the Port Master Plan (Fig. 3), in the reference scenario of 2025, shows that the current configuration causes a considerable beach retreat.

According to this simulation, the expansion of the port would trigger phenomena of sediment redistribution along the shoreline.

This area is also entirely within the Site of Community Importance (SCI) "Mouth of the Biferno River - Campomarino Coast", where the retreat of the sandy and the strong 
human activity are causing the destruction of dunes and pine forest now in contact with sea water.

The presence of the mouths of the two rivers, Trigno and Biferno, interspersed by the promontory of the old town with its harbor, generates, in a few tens of kilometers, a strong and continuous alteration of the beach and the coastal landscape.

\section{RESULTS AND CONCLUSIONS}

The same operation we made also for other Plans which exist in this area.

By overlapping the Landscape Plan with the Master Plan of Industrial Centre, it emerges that our sample area falls in $\mathrm{M}$ zones, i.e. at medium sensitivity to processing, where there is a prevalence of high and average values.

The more inner part, where there are plans to build a new Inter-Port, is characterized as MV1 area (Areas with exclusive high degree perceptive values) for which perceptive values are evidenced, while in its south part, which is the most affected by the presence of industries, the zone is classified as MS (Areas of the settlement system with average perceptive value).

Comparing them, however, compatibility of transformations emerges, so we can say that two Plans do not conflict with each other and therefore do not cause any inconsistencies.

Overlaying, however, the Master Plan of Industrial Centre with the Termoli Master Plan, a discrepancy could be detected.

In fact, the area located between the highway and the area assigned to the Inter-Port, nowadays is highly specialized and it is characterized by intensive agricultural vocation. For the City Master Plan it is correctly categorized as E1 (green agricultural area), while in the zoning Master Plan of Industrial Centre it is considered as an area for industrial activities.

Also about the coastline, there are some problems.

Along the coast, as shown in Fig. 3, there is the already mentioned area of the SCI "Mouth of the Biferno River- Campomarino Coast" (IT7222216).

For the Landscape Plan No. 1, covering all beaches, the coastal pioneer vegetation is considered of fundamental importance in terms of recovery and environmental redevelopment. In this zone the restoration and maintenance of the existing activities are allowed.

The beaches zoning plan, in this strip of territory, refers to a functional mix, defining the areas as recreation areas, areas of public interest, given the concession areas, free areas and restructuring areas, even if they are affected by severe erosion and environmental degradation, as shown in Fig. 4.

In conclusion, testing our methodology on the Molise waterfront transformations, several important elements should be considered.

From an analysis of natural and anthropic evolution over the last century, it can be seen that the Molise's coastal strip has been and still is subject to two types of risk: (a) risks determined by man's multiple activities; (b) natural risks determined by the overall evolution of the coastline and by the natural, spontaneous and induced phenomena to which it is subject.

(a) As regards manmade risk it must be considered that the coastal territory underwent deep transformations caused by the various human activities of both private and public initiatives. The expansion of tourist areas has involved and continues to involve the beaches around the River's mouths, with the consequent transformation of many kilometers of coast caused by the construction of hotels, residences, the parcelling out of land to private individuals, tourist ports, infrastructures, car parks, coastal roads, seafronts with facilities. 


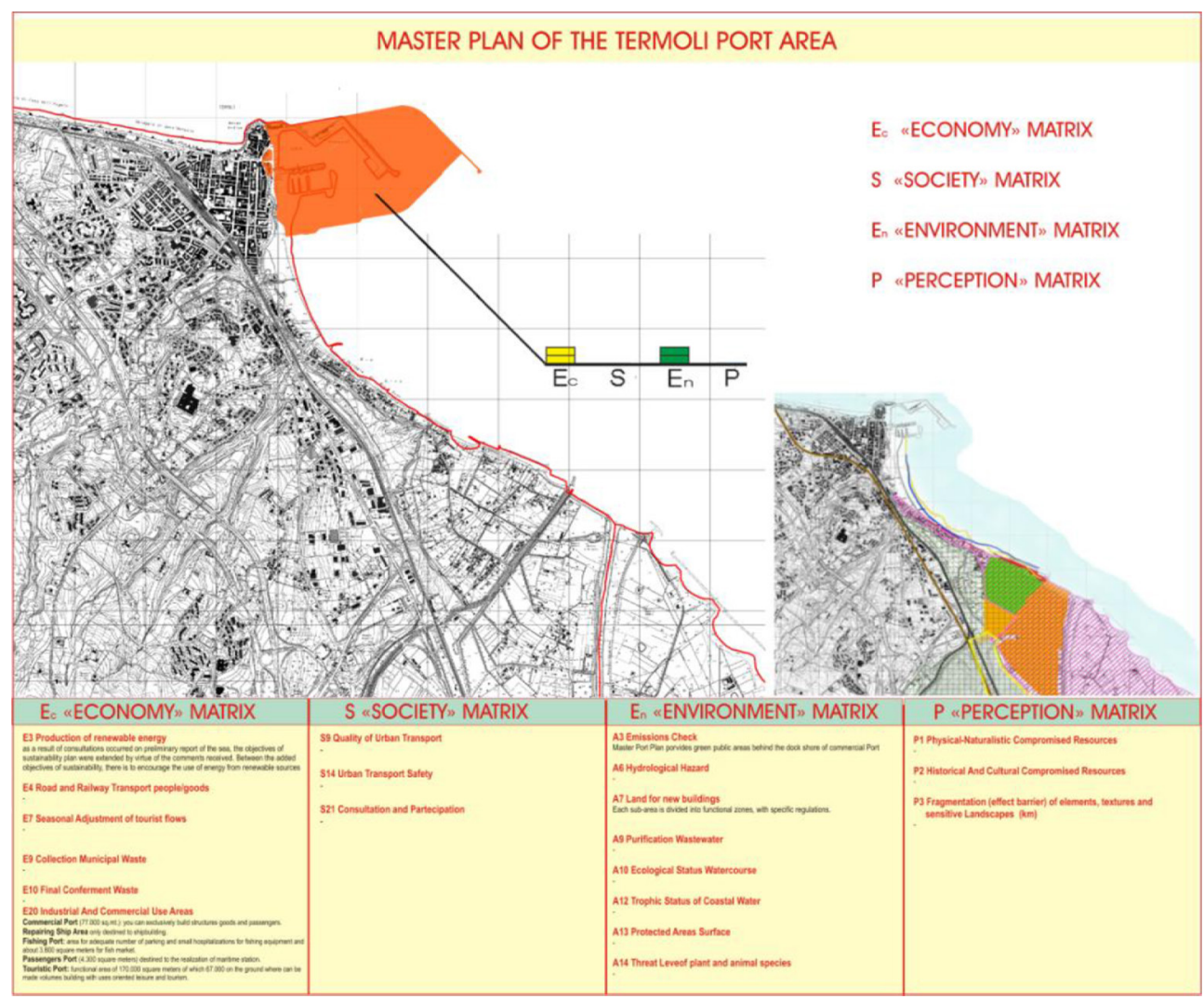

Figure 4: Master Plan of the Termoli Port Area Analyses (Sources: Municipality of Termoli, Quercio 2015 Processing Laboratory 1.a.co.s.t.a. 2013).

(b) As regards environmental risk, one of the major factors is that of coastal erosion which in little more than half a century has cancelled thousands of square meters of beaches and dunes. According to studies by the EU's Erosion Commission, 89.5\% of the Molise coast is affected by the constant loss of sediments, which are no longer replaced by the sediments carried and deposited by the rivers. This negative evolutionary trend is confirmed by the periodical studies on erosion undertaken in the last few years and shows a heavy withdrawal of most of the Molise's shoreline from 1950 onwards.

The Molise dunes constitute an ecological continuum which proceeds north along the coastline of Vasto in the Abruzzo region and to the south with the sandy coast of Apulia as far as the Gargano peninsula. The sand growing vegetation of the dunes is of great importance as it contributes in a decisive manner to the construction and the heightening of the dunes by holding and accumulating the grains of sand carried by the wind.

The lack of a territorial plan remains one of the major obstacles for sustainable coastal development which should aim towards the creation of adequate sector plans in accordance with those of a higher level. Moreover, the inefficiency of the government, from the National to the Regional level, has caused enormous gaps in the territorial planning system, rendering possible the uncontrolled spread of urban centers and the loss of areas with high landscape and natural value. 


\section{REFERENCES}

[1] Quercio, N., Rigenerazione delle aree costiere. Aspetti paesaggistici e progettuali del waterfront, tesi di dottorato in "Analisi e Valorizzazione del paesaggio" coordinatore prof. Donatella Cialdea, Università degli Studi del Molise, 2015.

[2] Cialdea, D. (ed), Research Methodology. Territorial Survey Interreg Reports. Materials for Adriatic Cross Border Project Report no. 1. Progetto GES.S.TER. / Interreg IIIA, Campobasso Arti Grafiche La Regione, 2005.

[3] Cialdea, D. (eds), Land Use Evaluation. Analysis in the Different Landscape Performances, Interreg Reports. Materials For Adriatic Cross Border Project Report no. 2 Progetto GES.S.TER. / Interreg IIIA, Campobasso Arti Grafiche La Regione, 2006.

[4] Cialdea, D. (eds), Environmental Assessment Interreg Reports. Materials for Adriatic Cross Border Project Report no. 3. Progetto GES.S.TER. / Interreg IIIA, Campobasso Arti Grafiche La Regione, 2007.

[5] Cialdea, D. (eds), A Network for Local Identities Value Interreg Reports. Materials for Adriatic Cross Border Project Report no. 4. Progetto GES.S.TER. / Interreg IIIA, Campobasso Arti Grafiche La Regione, 2013.

[6] Cialdea, D., Planning activities in coastal areas: Italian and cross-border approaches along the Adriatic Sea. International Journal of Sustainable Development and Planning, in press.

[7] Bruttomesso, R., Nuovi scenari urbani per le città d'acqua, Milano, Italia Nostra, 7 marzo 2007.

[8] Bruttomesso, R. \& Moretti, M., Città-porto e riqualificazione del waterfront: evoluzione e scenario di una strategia vincente. In Waterfront d'Italia. Piani, politiche, progetti, Franco Angeli, ed. M. Savino, Milano, pp. 18-27, 2010.

[9] Carta, M., Città liquida. I waterfront urbani come generatori di qualità. In Governare l'evoluzione. Principi, metodi e progetti per una urbanistica in azione, ed. M. Carta, FrancoAngeli, Milano, 2009.

[10] Lino B., Aree urbane di waterfront in contesti "sensibili": sostenibilità, pianificazione "multipla" e integrata, in Atti della XV Conferenza Nazionale SIU Società Italiana degli Urbanisti "L'urbanistica che cambia. Rischi e valori, Planum. The Journal of Urbanism, n. 25, vol. 3/2012.

[11] Regione Puglia, Legge regionale 29 luglio 2008 n. 21, Norme per la rigenerazione urbana.

[12] Regione Toscana, Legge regionale 10 novembre 2014, n. 65, Norme per il governo del territorio.

[13] City of Aalborg, Aalborg Commitments Secretariat, The Aalborg Commitments inspiring futures, 2004.

[14] ICLEI Local Governments for Sustainability, European Secretariat, Freiburg, Germania. Linee Guida per l'attuazione degli Aalborg Commitments. Un approccio metodologico a 5 fasi, European Secretariat GmbH, 2007.

[15] Unione Europea, Carta di Lipsia sulle Città Europee Sostenibili, 2007.

[16] Wasser stadt GmbH, Centre Cities on Water (2000), 10 Principles for a Sustainable Development of Urban Waterfront Areas, Berlin: Urban Future (URBAN 21) Conference; July 2000.

[17] Hussein, R.M.R., Sustainable urban waterfronts using sustainability assessment rating system. World Academy of Science, Engineering and Technology International Journal of Civil, Environmental, Structural, Construction and Architectural Engineering, 8(4), pp. 488-498, 2014. 
[18] Giovinazzi, O. \& Moretti, M., Città portuali e waterfront urbani: trasformazioni e opportunità in TeMA 03.09 Trimestrale del Laboratorio Territorio Mobilità e Ambiente TeMA Lab, Vol 2 - No 3 - settembre 2009 - pp. 7-16, 2009.

[19] Sepe, M., La trasformazione di un waterfront urbano, in XXXII Conferenza Italiana di Scienze Regionali Rigenerazione Creativa e Sostenibilità, 2011.

[20] Carta, M., Dal waterfront alla città liquida. In Waterfront d'Italia. Piani, politiche, progetti, ed. M. Savino, Franco Angeli, Milano, pp. 31-32, 2010.

[21] National Oceanographic and Atmospheric Administration U.S. Department of Commerce. Smart Growth for Coastal and Waterfront Communities, USA, 2009.

[22] New York City Department of City Planning, Vision 2020, New York City Waterfront Plan-Comprehensive, 2011.

[23] New York City Department of City Planning, The New York City Waterfront Revitalization Program, 2002.

[24] New York City Department of City Planning, The New York City Waterfront Revitalization Program Approved Revisions, 2013.

[25] Consiglio Nazionale dell'Economia e del Lavoro, Rapporto Finale. Indicatori per lo sviluppo sostenibile in Italia, 2005.

[26] Zezza, A., Sviluppo sostenibile e agricoltura biologica. In Abitabile C. e Arzen A. (eds.), Misurare la sostenibilità dell'agricoltura biologica, INEA, 2013.

[27] Consiglio dell'Unione Europea, Nuova strategia europea per lo sviluppo sostenibile, Bruxelles, 2006.

[28] Nazioni Unite, Rapporto della Conferenza delle Nazioni Unite sull'ambiente e lo sviluppo, Rio de Janeiro, 1992.

[29] Osberg, L. \& Sharpe, A., An index of economic well-being for selected OECD countries. Review of Income and Wealth, 48(3), 2002. http://dx.doi.org/10.1111/1475-4991.00056

[30] Nordhaus, W. \& Tobin, J., Is Growth Obsolete? In The Measurement of Economic and Social Performance, Studies in Income and Wealth, National Bureau of Economic Research, 38, 1973.

[31] World Bank, World development indicators 1999, Washington D.C., 1999 and successive integrated.

[32] Wackernagel, M. \& Rees, W.E., Our Ecological Footprint: Reducing Human Impact on the Earth, New Society Publishing: Philadelphia, 1996. 